\title{
CUALQUIER MEMORIA ES LITERATURA. \\ (MEMORIA LITERARIA Y PROCESO DE LA CREACIÓN)
}

\author{
Mercedes Comellas Aguirrezábal
}

Inventar, en el fondo, es recordar

Gerard de Nerval, Las hijas del fuego

... hay que tener en cuenta que si el hecho más agradable del presente no se puede recordar, se reduce a casi nada. Nuestra vida es historia, no sólo nuestros hechos exteriores, sino nuestra personalidad interior.

Pío Baroja, El gran torbellino del mundo.

En su afán de encontrar unidad en la Verdad, Platón abomina de aquel ejercicio por el que la palabra bella es capaz de crear mundos ficticios, criaturas de la irrealidad susceptibles de confundirnos entre el ser y el no-ser, de enturbiar la transparencia filosófica sirviendo como espejo oscuro a la verdad ${ }^{1}$. Esta renuncia sea quizá -sin pretenderlo- uno de los más hermosos y antiguos tributos que se le han rendido a la literatura: reconocer su poder para sembrar la ambigüedad en el mundo de la luz y de los hombres, para borrar sus límites exactos.

Y esta capacidad falsaria y mágica de la palabra poética tiene sus raíces en el proceso de interiorización por el que lo literario se aloja en los senos de nuestra imaginación, forjando allí imágenes a la medida de las palabras, -que no de las cosas-, fantasmas de lo irreal que, acomodados en nuestra memoria, van construyendo como parásitos monstruosos un segundo mundo en peligrosa connivencia con el primer mundo, éste de las especies

\footnotetext{
${ }^{1}$ Sofista 264-266e. El diálogo se destina a criticar la sofística a través de la negación del Uno-Todo parmenidiano, demostrando, contra la teoría de Parménides de que jamás se conseguirá que sea lo que no es, que el concepto del ser es tan oscuro como el del no-ser y que el no-ser tiene entidad real. La demostración del no-ser utiliza como argumento precisamente el ejercicio de la retórica: "nuestro sofista de las cien cabezas nos ha forzado a reconocer, bien a pesar nuestro, que el no-ser es de alguna manera [...] Cuando, asignándole como campo suyo de operaciones el simulacro y como obra suya el engaño, afirmemos que su arte es un arte de la ilusión, diremos entonces nosotros que nuestra alma se forma en las opiniones falsas como consecuencia de su arte." Traducción de Luis Gil en Platón, Obras completas, Aguilar (Madrid 1974) 1020.
} 
sensibles con entidad real. Al fin y al cabo, en palabras de Emilio Lledó, “el logos sintetizó, además, una cierta forma de experiencia de lo real, cuando eso real ya no estaba presente. [...] hablar era, esencialmente, una forma viva también, de recordar"2. Más poderosa aún en su artificio, la experiencia literaria se confunde con la experiencia vital sin que al cabo quede la posibilidad de deshacer el entuerto. En frase famosa de don Miguel de Unamuno, "todos somos bíblicos, pues sin leer no existiríamos". Y mucho más cercano en el tiempo Fernández-Molina hace suyos unos versos de Pierre Reverdy quien, "identificando la pluma con el puñal que hiere y la tinta con la sangre, asegura que la vida ficticia es más deliciosa y real que el abismo familiar que nos traga a diario" ${ }^{13}$. De tal negocio oscuro se defiende en estremecedora -por lo impotente- venganza el "quemalibros" Pepe Carvalho, que suele

"de noche vengarse inútilmente de la cultura que le había aislado de la vida ¿Cómo amaríamos si no hubiéramos aprendido en los libros cómo se ama? ¿Cómo sufriríamos?"4.

Mucho más terrible se siente la confesión - ¿y arrepentimiento?-, no ya de un ser de ficción, sino de un hombre, aunque casi metamorfoseado personaje literario, como su nombre confirma, Azorín, que en los últimos años de su vida escribe:

\begin{abstract}
“¡Ah, el castillo! Digo a los amigos, con profunda tristeza, que no he subido nunca al castillo y que me voy a morir sin haber subido, y los amigos sonríen. No puedo subir ahora, porque la subida es peligrosa, aunque se tomaran todas las precauciones, siempre resultaría que, con mis achaques, sería una temeridad la ascensión. Como no me doy por vencido, trato de recordar si, en efecto, no he subido al castillo o si, olvidado de haber subido, no me es posible la recordación. Y en estas dudas paso noches crueles. Condenso en este sentimiento toda una vida que he dedicado a los libros, y no a la realidad. Y esta vida inaprovechada se me va acabando ya. Se me acaba sin haber subido yo al castillo..."
\end{abstract}

En una de sus últimas entrevistas, la escritora Ana María Matute, afirmaba: "vivir y escribir es igual para mí, todo lo que yo hago es literatura, yo soy literatura"s. Y Antonio Muñoz Molina reconoce "haber amado tanto a los libros y de haberlos preferido en secreto a la vida" e indaga

"en qué medida y por qué lo real puede importarnos menos que lo imaginado, por qué caminos una rigurosa invención se vuelve verdadera [...] qué parte de ficción hay en la realidad, qué parte de realidad hay en la ficción"6.

\footnotetext{
${ }^{2}$ Emilio Lledó, “Memoria y escritura”, El silencio de la escritura, Espasa-Calpe (Madrid 1991) 22.

${ }^{3}$ Fernández-Molina, Cantata en el iceberg, Libros Pórtico (Zaragoza, 1996).

${ }^{4}$ Vázquez Montalbán, Los mares del Sur, Planeta (Barcelona 1988) 190.

${ }^{5}$ El País, 7 de julio de 1996, 60.
}

${ }^{6}$ Antonio Muñoz Molina, Pura alegría, Alfaguara (Barcelona 1998) 25. Aunque en otros escritores vida y literatura se oponen con ferocidad mutua. Así lo observa Elide Pittarello en su introducción a Javier Marías, Todas las almas, Círculo de Lectores (Barcelona 1992) 7: "Para Javier Marías [...] la palabra y la vida están hechas de tiempo, pero no sólo la palabra no se parece a la vida, ni la reemplaza o la simula, sino que surge a raíz de su pérdida irreparable, de su definitivo ocaso. [...] La naturaleza abstracta de la palabra no sólo no tiene que ver con 
Cuando el poeta escribe, recurre a esa doble vida, la suya y la de sus libros, confesadas siamesas que comparten una misma memoria: memoria de la emoción, del conocimiento, de la soledad, memoria común de vida y literatura en confidencial intimidad que fue trenzando los itinerarios y jornadas de una biblioteca vital, según reconoce Auden:

"Los viajes de Gulliver camina del brazo con un romance, un canto del Paradiso alterna con una espléndida cena, La Guerra y la paz nunca se aparta de la funesta pecunia de una Navidad en una ciudad extranjera, la décima versión de The Winter's Tale intercambia saludos con la primera grabación completa de La Favorita. Y sin embargo, éste es el mundo del cual emergen los poemas"?.

Desde la teoría literaria lo explica Yuri Lotman en su Estructura del texto artístico: la propiedad del arte de construir modelos de la realidad hace que cada receptor proyecte el mensaje artístico "no sólo sobre la estructura de su experiencia artística, sino también sobre

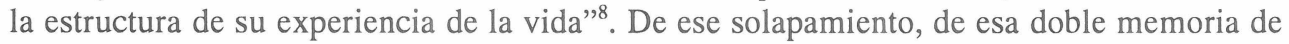
la experiencia brota la literatura, antes que del sentimiento espontáneo y directo. En contra de lo que cierta estética visionaria del Romanticismo quiso hacer creer, (con no poco éxito entre los lectores ingenuos ${ }^{9}$ ), la emoción primaria es raras veces el agente de la inspiración; y una de las mejores pruebas puede ser la matización que el propio Wordsworth, hizo en el prefacio a la cuarta edición de las Baladas líricas a su famosa definición de poesía como espontáneo desbordamiento de intensas emociones:

la naturaleza concreta de la vida, sino que se da sólo en su radical negación, tras la muerte absoluta de los personajes que dejaron de ser para siempre y tras la muerte relativa del narrador que va dejando de ser día a día."

${ }^{7}$ W. H. Auden, La mano del teñidor, Barral (Barcelona 1974) 50-1.

${ }^{8}$ Yuri Lotman, Estructura del texto artístico, Istmo (Madrid 1982) 348. Sobre la oposición también muy interesante que establece Lotman (en "Consideraciones sobre la tipología de las culturas", Revista de Occidente ${ }^{\circ}$ $103,5-19)$ entre dos tipos de memoria, la colectiva textualizada -con escritura- y la no textualizada en formas de escritura. Ver Pozuelo Yvancos, "Etnoliteratura y semiótica de la cultura", en Manuel de la Fuente Lombo y $\mathrm{M}^{\mathrm{a}}$ Ángeles Hermosilla Álvarez, Etnoliteratura: Una Antropología de ¿lo imaginario?, Universidad de Córdoba (Córdoba 1997) 134. De dos memorias trata también Emilio Lledó, "Memoria y escritura", El silencio de la escritura, Espasa-Calpe (Madrid 1991) 22: "Por un lado, el pasado común de la lengua que preexiste como gran memoria colectiva ["lengua cargada con la experiencia que han ido acumulando las pasadas generaciones"], por otro lado, el concreto pasado individual del que cada uno habla y que, en su hablar, comunicándolo, universaliza".

${ }^{9}$ Victor Hugo, prólogo a Cromwell, en Manifiesto romántico, Ediciones Península (Barcelona 1989) 65: "tratemos de indicar cuál es el límite infranqueable que, a nuestro juicio, separa la realidad según el arte, de la realidad según la naturaleza. Confundir ambas realidades, como lo hacen algunos partidarios poco avanzados del Romanticismo, significa atolondramiento" (la cursiva es mía). Es muy numerosa la lista de románticos que en algún momento insistieron en la necesidad de reflexión y artificio, negando la espontaneidad del acto creativo. Recuérdese entre los Frühromantiker a A. W. Schlegel, para quien, aunque acepte que la creación surge de la fantasía, el arte requiere el estilo, que es la herramienta del artificio; contra la teoría del origen órfico y místico de la poesía (que en su época se denominó el "unbewußtes Schaffen") que entiende los principios artísticos en orgías, festejos, exaltaciones, inspiración, etc., Schlegel, al contrario que Schelling, Hölderlin y más tarde Nietzsche y Rilke, supone el origen de la actividad poética en la época de Homero: el poeta cantor homérico no está exaltado sino reflexiona; de hecho afirma que con la separación entre poeta y visionario empieza el verdadero arte poética: sólo se puede hablar de poesía cuando el poeta elige libremente la materia, la adorna, combina y ordena ("freie dichterische Verknüpfung"). Ernst Behler, Klassische Ironie, romantische Ironie, tragische Ironie. Zum Ursprung dieser Begriff, Wissenschaftliche Buchgesellschaft, (Darmstadt 1972) 85 ss. 
"I have said that poetry is the spontaneous overflow of powerful feelings; it takes its origin from emotion recollected in tranquillity; the emotion is contemplated till by a species of reaction the tranquillity gradually disappears, and an emotion, kindred to that which was before the subject of contemplation, is gradually produced and does itself actually exist in mind." ${ }^{\prime \prime}$.

La emoción no tiene reflejo literario inmediato: el manantial poético tiene más oscuro origen: el de aquella emoción, pero una vez que ha sido fecundada en el recuerdo, gestada en su oscuro silencio y alimentada ya de la memoria literaria. El "viejo oficio de poeta", para José Agustín Goytisolo

\author{
"... comienza \\ en la idea; en el soplo \\ sobre el polvo infinito \\ de la memoria; sobre \\ la historia y los deseos \\ de mujeres y hombres."11
}

La idea hecha memoria, la historia, el deseo hecho recuerdo, son la carne de la materia poética. Demasiado descarnada resultarían la idea o el deseo en la agitación su primitivo arrebato. Se pregunta Diderot

“Acaso componéis un poema sobre la muerte del amigo o la amada en el mismo
momento en que acabáis de perderlos? No... Cuando ha pasado la intensidad del
dolor, cuando se amortigua la sensibilidad extrema, cuando ha quedado lejos la
catástrofe y el alma se serena, y se recuerda la felicidad perdida, y se aprecia la
pérdida que hemos sufrido, y la memoria se une con la imaginación... y se habla bien.
Decimos que lloramos, pero no se llora ya al perseguir un epíteto enérgico que nos
huye..., ni al dedicarnos a hacer armonioso un verso; o, si es que corren las lágrimas,
cae la pluma de las manos, se entrega uno al sentimiento y deja de componer"12

Custodiadas en la distancia del recuerdo, las vivencias emocionales cobran medidas literarias. Cuando a José Hierro se le preguntó si es necesario estar herido para hacer poesía, dio por respuesta:

"Es necesario haberlo estado. En el momento de la herida, bajo el impacto del suceso, no creo que se pueda escribir. La poesía necesita una emoción inicial, pero una reflexión posterior: es un ejercicio de lucidez. [...] de la realidad no se puede hacer poesía. Hay que hacer mentalmente una foto que se queda aquí, en la cabeza, pero luego se revela al cabo de los años. Es entonces cuando aparecen aquellas imágenes que ya no recordabas y resultan ser las mejores."13

\footnotetext{
${ }^{10}$ Cit. por S. Corugedo y J.L. Chamosa, prólogo la ed. de Baladas líricas, Cátedra (Madrid 1994) 38n.

${ }^{11}$ José Agustín Goytisolo, “Oficio de poeta”, Algo sucede (1968).

${ }^{12}$ D. Diderot, Oeuvres complètes, ed. de J. Assézat y M. Tourneux, 20 vols., París, 1875-1879, VIII, 368 y 386; traducción de René Wellek, Historia de la crítica moderna (1750-1950), Gredos (Madrid 1989) I, 72.

${ }^{13}$ Entrevista publicada en ABC Cultural, noviembre de 1995.
} 
Resulta inevitable recordar que casi ciento cincuenta años antes, otro poeta español, Gustavo Adolfo Bécquer, ofreciera, en la segunda de las Cartas literarias a una mujer, una formulación prácticamente idéntica del proceso de creación, donde también cifra en la memoria la distancia que separa la materia poética de la creación. Bécquer escribía:

"Si hemos de dar crédito [a los poetas], es una verdad tan innegable que se puede elevar a la categoría de axioma el que nunca se vierte la idea con tanta vida y precisión como en el momento en que ésta se levanta semejante a un gas desprendido y enardece la fantasía y hace vibrar todas las fibras sensibles[...] Yo no niego que suceda así. Yo no niego nada, pero por lo que a mí me toca, puedo asegurarte que cuando siento no escribo. Guardo, sí, en mi cerebro, escritas como en un libro misterioso las impresiones que han dejado en él su huella al pasar; estas ligeras y ardientes hijas de la sensación duermen allí agrupadas en el fondo de mi memoria hasta el instante en que, puro, tranquilo, sereno, y revestido, por decirlo así, de un poder sobrenatural, mi espíritu las evoca, [...], y cruzan otra vez a mis ojos como en una visión [...] Entonces no siento ya con los nervios que se agitan, con el pecho que se oprime, con la parte orgánica y material que se conmueve al rudo choque de las sensaciones producidas por la pasión [...]; siento, sí, pero de una manera que puede llamarse artificial; escribo como el que copia de una página ya escrita [...]

Todo el mundo siente.

Sólo a algunos seres les es dado el guardar, como un tesoro, la memoria viva de lo que han sentido.

Yo creo que éstos son los poetas. Es más, creo que únicamente por esto lo son.,"14

Según Bécquer, el poeta lo es por la memoria de sus impresiones. Según Hierro por la capacidad de hacer esa foto memorística. Según Antonio Muñoz Molina, la literatura toda es consecuencia, es hija de la memoria ${ }^{15}$. Las citas podrían acumularse y ocupar largas páginas: el tiempo de la creación no es muchas veces el tiempo de la emoción, aunque esto contradiga, como se señalaba arriba, cierta tendencia romántica a asegurar que el poeta, en aquel arrebato de alquimia lírica que es la inspiración, transforma inmediatamente el objeto en forma lírica ${ }^{16}$. Precisamente la condición del arte en la Naturphilosophie, y por la que se

${ }^{14}$ Gustavo A. Bécquer, Obras completas II. Narraciones. Cartas literarias a una mujer. Desde mi celda. Libro de los gorriones. Artículos, crónicas y cuadros. Miscelánea. Ed. de R. Navas Ruiz, Biblioteca Castro Turner (Madrid, 1995) 352.

${ }^{15}$ Véase José-Carlos Mainer, "Antonio Muñoz Molina ou la prise de possesion de la mémoire", Etudes, 380, 2 (1994) 235-246. No hace mucho se publicaban unas reflexiones de Antonio Muñoz Molina sobre la literatura como consecuencia de la memoria en el volumen colectivo Claves de la memoria (coord., José Ma Ruiz Vargas, Madrid, Trotta) que enjuician al escritor como la memoria viva de una sociedad.

${ }^{16}$ En su Eugenio Onieguin y como explicación del proceso de idealización poética por el que realidad y literatura se separan no sin confusiones, el mayor romántico ruso, Pushkin, señala la necesaria distancia entre el momento de la pasión y el de la redacción literaria: "Y cuando me pongo a escribir, en mi corazón reina una tranquilidad profunda [...] Las cenizas apagadas no pueden reavivar el fuego, por esta razón, a pesar de mi tristeza, las lágrimas no humedecen mis mejillas, y pronto borrará de mi memoria incluso el mismo recuerdo de la tormenta. / Únicamente entonces me será posible intentar, señores míos, escribir una obra poética de veinticinco capítulos".]A. Pushkin, Eugenio Onieguin, Bruguera (Barcelona 1969) 58-9. 
convierte en pilar epistemológico, es la de conciliar el consciente con el inconsciente en un proceso dual de la creación; así es presentado por Schleiermacher como un receso temporal que marca aquella intensa frontera entre la emoción y la escritura:

"la esencia del estado no artístico es que en él la excitación y la expresión son idénticas y perfectamente simultáneas, nacen juntas, unidas por un vínculo inconsciente, y se extinguen una con otra; o, para decirlo con mayor concreción, ambas son en verdad una sola cosa, y sólo el espectador las espera arbitrariamente desde fuera, mientras que, por el contrario, en el rendimiento artístico esta identidad queda fundamentalmente abolida. La excitación en sí nada sabe de la norma y la medida, sino que, allí donde encontramos sus expresiones habituales colocadas bajo el orden y transformadas en elementos artísticos, lo que aparece exteriormente también ha sido modelado interiormente. Otra fuerza más elevada se ha interpuesto, y ha separado lo, de otro modo, indisolublemente unido; el momento de la cognición se encaja, por así decirlo, separando, y rompe ya, por tanto, merced a su persistencia, el campo de aquella fuerza bruta de la excitación, deteniéndolo, al tiempo que se fortalece como un principio regulador mientras mantiene en suspenso el movimiento ya introducido. Así pues, es éste el momento por el que el arte se distingue del mero proceso natural, es el momento de la concepción, en el cual se modela en el interior lo que después aparece exteriormente."17

Entre la percepción del objeto o su experiencia y la formalización por el lenguaje, transcurre un fragmento temporal que marca la distancia entre la materia literaria y la creación, y que tiene por principal protagonista (lo afirmaban nuestros poetas), a la memoria, una suerte de eslabón que une en la distancia del recuerdo el objeto del poema y su ejecución. La memoria, desde la antigua concepción médica de los humores, se consideró una de las principales potencias cerebrales. Así lo declara el humanista Juan de Pineda en sus conocidos y divulgativos Diálogos familiares de la agricultura cristiana, asegurando que "las facultades doctrinales dependen de la memoria o del entendimiento o de la imaginativa"18. Y también Fernando de Herrera cuando enumera "las tres facultades interiores de la ánima [...a saber]: la memoria, la razón y la fuerza de imaginar, que es la fantasía" ${ }^{19}$. En el proceso de creación, junto al entendimiento y la imaginación, la memoria actuará como tercera fuerza mental, según se explicaba también en la medicina antigua.

Las aplicaciones creativas de esta distancia temporal y de esta fuerza mentalno se han mantenido siempre idénticas a lo largo de la historia literaria, sino que su ministerio se ha presentado de varias formas diversas, algunas de las cuales trataremos de presentar en lo que sigue.

Quizá la más antigua función de la memoria en la creación literaria occidental es la que podríamos llamar memoria histórica, entendiendo por histórico el anchuroso campo que

${ }^{17}$ Friedrich Schleiermacher, Über den Umfang des Begriffs der Kunst in Bezug auf die Theorie derselben, en Sämtliche Werke, III, Reimer (Berlín 1835) 191-193. Cit. por Fragmentos para una teoría romántica del arte; antología de Javier Arnaldo, Tecnos (Madrid 1987) 47-8.

${ }^{18}$ Cfr. A. Porqueras, La teoría poética en el Renacimiento y Manierismo españoles, Puvill (Barcelona 1986) 148.

${ }^{19}$ F. de Herrera, Anotaciones a Garcilaso, ed. de A. Gallego-Morell, Garcilaso y sus comentaristas, Gredos (Madrid 1972) 322. 
ocupara antes de que la historia y la fábula fueran escindidas por los pruritos científicos de la Ilustración ${ }^{20}$. Construye esta memoria histórica una poética del recuerdo bastante elemental y de la que da cuenta la más primitiva poética: la mitológica. La mitología grecolatina -que no predica componendas genéticas en vano ni arbitrariamente-, cuenta que Mnemósine, la potencia de la memoria, es madre de las musas, origen y principio de todas las artes; sus dos vástagos principales son la poesía y la historia. En el caso de la historia es obvia la función de la diosa, pero en el de la poesía, si hoy no tanto para nosotros, también lo fue para los griegos, cuyo pasado pseudo-histórico y mítico constituía el material poético por excelencia. De hecho el rapsoda es el que recuerda los tiempos antiguos y los canta; su función la de rememorar y traer de nuevo al presente el poso poético, y la función de la memoria, convertida en musa, proporcionar al poeta los motivos y los contenidos literarios ${ }^{21}$. El poeta, capacitado de forma particular para ponerse en relación con el Olimpo, comienza ritualmente invocando a las Musas por una serie de fórmulas que poco a poco irán cobrando pura entidad retórica: ellas han sido testigos de aquello que ahora el poeta debe cantar; como hijas de Mnemósine, conocen el pasado, presente y futuro y lo han visto todo, "poseen un conocimiento ocular de los hechos, en tanto que los hombres dependen de la tradición oral y nada seguro saben"22. Ellas revelan al poeta, en proceso de comunicación religioso, el argumento, la historia sobre la que se construye la obra. El poeta sólo es portavoz, intérprete de aquellas voces que le muestran el camino.

La memoria histórica permanecerá más allá de los tiempos arcaicos en los géneros que se deriven de estos primeros: desde Homero, la memoria histórica es la memoria de la épica, la de aquellas epopeyas que cantaron las hazañas de los héroes, y también es la que enseñorea otros géneros más modernos: la biografía o la novela histórica. Los materiales que a éstos proporciona, hermanos de la historia, se ayuntan con la ficción construyendo un segundo texto que escapará al control de la veracidad originaria para revivirse en los más vastos dominios de una verdad fabulosa. Las formas y géneros propios de la memoria histórica implican el recuerdo de otro tiempo, un tiempo anterior que se convierte en materia literaria. La distancia temporal que de él nos separa ha servido a los intereses

${ }^{20}$ Paul Hazard, El pensamiento europeo del siglo XVIII, Alianza (Madrid 1985) 213ss: la renovación de la historiografía exigió en primer lugar el divorcio de la Historia y la fábula. Son muy frecuentes las invitaciones a una narración fiel, un relato exacto, apoyado en testimonios. (Véase Lenglet du Fresnoy, L'Histoire justifiée contre les romans, 1735); incluso se llegaron a inventar fórmulas matemáticas para establecer el crédito que debía darse a las afirmaciones.

${ }^{21}$ J. P. Vernant (Mito y pensamiento en la Grecia antigua, Ariel, Barcelona 1973) ha estudiado y considera muy notable "la divinización de la memoria y la elaboración de una amplia mitología del recuerdo en la Grecia arcaica".

${ }^{22}$ En palabras muy citadas de Píndaro: "Predice, oh Musa, y yo seré tu intérprete". Luis Gil, Los antiguos y la «inspiración» poética, Guadarrama (Madrid 1967) 19. Ver además Jacques Le Goff, El orden de la memoria. El tiempo como imaginario, Paidós (Barcelona 1991) 145: En la Grecia antigua, “el poeta es [...] un hombre poseído por la memoria, el aedo es un adivino del pasado, así como el adivino lo es del futuro. El es el testimonio inspirado de los 'tiempos antiguos', de la edad heroica y, aún más, de la edad de los orígenes. La poesía, identificada con la memoria, hace de ésta un saber e incluso una sabiduría, una oopı . El poeta tiene su puesto entre los 'maestros de la verdad' y en los orígenes de la poética griega la palabra poética es una inscripción viviente que se imprime en la memoria como en el mármol. Para Homero - [...]- componer versos era recordar." Un resumen de la teoría y varias citas ilustrativas pueden encontrarse también en la Historia de la teoría literaria I. La Antigüedad grecolatina, coord. por Carmen Bobes, Gredos (Madrid 1995) 33-35. 
poéticos como margen idealizador que difumina las exigencias de realidad, actuando como filtro entre los hechos y su fabulación.

Al segundo tipo de memoria le llamaremos memoria textual. Está íntimamente relacionada con la conocida fórmula de la imitatio, base que fue de toda la creación literaria hasta el Romanticismo, cuando con la revolución que iniciaron los teóricos alemanes, la originalidad, hasta entonces gesto de locura, pasó a convertirse en criterio rector de la creatividad. La fórmula de la imitatio, convertida en técnica tal como la aplicara la tradición latina, no implicaba ya, como en los presocráticos y Platón, la imitación directa de la naturaleza, sino que proponía la mejor manera de lograr éxito en la práctica literaria imitando a aquellos autores que con mayor fortuna les habían precedido. Las técnicas de la imitación significaron el inicio de la tradición clásica al plantearse como un aprendizaje sobre el recorrido de los mayores: todo lo que un autor puede desear escribir había sido escrito antes y la originalidad, además de imposible, es una pretensión absurda; el único margen que queda abierto a la creación personal del autor, eliminada la posibilidad de escribir algo nuevo, es la formalización distinta de los materiales y el desarrollo peculiar que se les preste. En unos versos que pasaron a convertirse en código ordinario, explica Horacio cómo el poeta puede seguir y usar los temas tradicionales sin ser un imitador servil, ganando así "derechos privados en suelo público"23:

"La pública materia de tu derecho privado será, si no te quedas dando vueltas a un ciclo vil y pateado, ni te preocupas por reproducir palabra por palabra, cual fiel intérprete"24

Desde Horacio hasta Moratín, cuyas afirmaciones resultan hoy mucho más restrictivas que las del latino, median dieciocho siglos de historia de la imitación:

"Lo que se llama inventar en las artes no es otra cosa que imitar lo que existe en la naturaleza, o en las obras de los hombres, que la imitaron ya. El que se proponga no coincidir nunca en lo mismo que otros hicieron, se propone un método equivocado y absurdo, y el que huye de acomodar en sus obras las perfecciones de otro artífice, pudiendo hacerlo con oportunidad, voluntariamente yerra $[\ldots]^{25}$

La parábola de las abejas, que sirviera a los clásicos y después a los humanistas del Renacimiento para explicar el proceso imitativo, resulta mucho más expresiva y menos limitada que las palabras de Moratín al ilustrar sobre el sentido de este aprendizaje y del aprovechamiento textual en la propia creación. El mito, de ascendencia sánscrita, trascendió

\footnotetext{
${ }^{23}$ Tiene en cuenta también Horacio los consejos de Aristóteles, que en el cap. 9 de la Poética declara que el autor no se debe atener estrictamente a las historias tradicionales, sino que puede variarlas: "Y no comienza la vuelta de Diomedes desde la muerte de Meleagro ni la guerra de Troya desde los huevos gemelos, siempre al desenlace se apresura y hacia el meollo, como si fuera conocido, al oyente arrastra y, lo que no desespera de que, al tratarlo, pueda brillar, lo deja y miente y mezcla verdad con ficción".

${ }^{24}$ Traducción de Horacio Silvestre en Horacio, Arte poética, Cátedra (Madrid 1996) 146-151.

${ }^{25}$ Moratín, Teatro completo, ed. de F. Lázaro, Labor (Barcelona 1970) vol. 1, 232.
} 
a la tradición grecolatina hasta encontrar cabida precisa en los autores del humanismo italiano que lo retomarían como alegoría de la teoría poética.

" Debemos comportarnos e imitar la labor de las abejas cuando en el prado florecido pululan, y eligen para libar las flores más dulces y hermosas, extrayendo de ellas la miel: igualmente, al leer los libros de los oradores y poetas, debemos imitar lo mejor de todo, y así como las abejas no reproducen las mismas flores sino algo aún mejor que las flores mismas, que es la miel, tampoco nosotros podemos repetir los dichos de los oradores y poetas que queremos imitar copiando letra por letra, sino transformándolos en jugo personal." 26

El poeta es la abeja y el campo de flores la tradición; la miel, obra propia, es el resultado de la elaboración personal de su libar entre los mejores escritores antiguos, cosecha mejor y nueva según exigía Petrarca al recoger el mito en sus Familiares ${ }^{27}$. Pero si el poeta debe comportarse como la abeja, es necesario previamente que conozca bien las propiedades del prado y de las flores que lo colorean, es necesario que en la memoria haya almacenado el material recogido en la abundante lectura para después, por diversos métodos, hacerlo propio. La formación poética reclamaba conocer perfectamente la obra de los mayores, y el oficio exigía una generosa memoria textual que les permitiera, en el momento adecuado, servirse de aquel arsenal de versos. Sin este bagaje la poesía pierde toda justificación y autoridad, ni siquiera alcanza la categoría literaria:

"afirmo que no tengo por buen poeta al que no imita los excelentes antiguos. Y si me preguntan por qué entre tantos millares de poetas como nuestra España tiene, tan pocos se pueden contar dignos deste nombre, digo, que no hay otra razón sino porque les faltan las ciencias, lenguas y dotrina para saber imitar. Ningún poeta latino hay que en su género no haya imitado a otros, como Terencio a Menandro, Séneca a Eurípides; y Virgilio no se contentó con caminar siempre por la huella de Homero, sino también se halla haber seguido a Hesíodo, Teócrito, Euríídes..." ${ }^{28}$

También su amigo Fray Luis de León, como los mejores latinos, supo imitar y construir así la única poesía que sancionaría el juicio del Brocense: aquella que delata el cuerpo vivo de la tradición en su entramado, que bebe de los mayores recuperándolos, incluso en las palabras y las frases, para el presente, para la propia emoción; emoción que no desaparece, sino que se encarna en memoria literaria, en memoria de otros textos. Ya demostró Fernando Lázaro Carreter hasta qué punto era la «Oda a Grial» un constructo literario,

\footnotetext{
${ }^{26}$ Séneca, Epistulae morales, 52-57: "Sicut enim apes in prato florenti pleno vadunt, flores candidiores et electiores sugunt, et extrahunt mel, ita et nos volentes imitari, quando libros oratorum et poetarum et imprimis Ciceronis nostri legimus, electiora dicta imitari debemus, et sicut ipsae apes non auferunt ipsos flores secum sed tantum id quod potest a floribus accipi, scilicet mel, ita et nos non accipiamus dicta oratorum et poetarum quos imitari volumus recte secundum litteram, sed imitemur ita ut non videamur ipsa furari". Un magnífico trabajo sobre la tradición del mito se encuentra en Stackelberg, "Das Bienengleichnis. Ein Beitrag zur Geschichte der Literarischen Imitatio.", Romanische Forschungen, LXVIII (1956), 3-4, 271-293.
}

${ }^{27}$ F. Petrarca, Familiari, I, 7.

${ }^{28}$ F. Sánchez de las Brozas, prólogo a las Anotaciones a Garcilaso. En Humanistas españoles, ed. de Ana M. Arancón, Editora Nacional (Madrid 1980) 513-514. 
donde de casi cada minúscula pieza puede demostrarse su procedencìa libresca ${ }^{29} \mathrm{y}$, sin embargo, a nadie cabe dudar cuán presente está la verdad de Fray Luis, su desalentado abandono, en aquel perfecto ejemplo de imitación compuesta.

No acaba ni mucho menos el papel de la memoria textual en la literatura moderna, aunque sí es cierto que dejará de ser el más reclamado y encomiado. Sobre todo cambia el papel que dichos textos hayan de jugar en aquel en que se integran: ya no como memoria erudita ni demostración de conocimientos poetológicos, sino como literatura experimentada, asimilada vitalmente, alimento espiritual y moral, incluso como recuerdo de la propia emoción de su lectura. Por eso ahora, cuando Hugo emplea todavía la famosa parábola de las abejas lo hace para referirse precisamente al nuevo concepto de originalidad, asociado a la explicación orgánica de la obra de arte: no existen reglas a priori, sino que el genio las extrae

"no a la manera del químico que enciende su horno, aviva su fuego, calienta su crisol, analiza y destruye; sino a la manera de la abeja, que vuela llevada por sus alas de oro, se posa en cada flor y extrae su miel sin que el cáliz pierda un ápice de su esplendor, ni la corola un ápice de su perfume",30

Antes que él, Goethe se burlaba de la indagación de fuentes para insistir en la independencia de la fuerza creadora; con este fin recurre a otra imagen -menos alegórica que la de las abejas pero aún más significativa si cabe y con idéntico origen en Séneca- del proceso de interiorización y absorción de las lecturas y de cómo éstas configuran una memoria textual que el poeta acaba por hacer totalmente propia:

"Igualmente se podría preguntar a un hombre bien alimentado por los bueyes, corderos y cerdos que ha comido y le han dado fuerzas... Yo debo mucho a los griegos y los franceses, debo infinitamente a Shakespeare, Sterne y Goldsmith. Sólo que con ello no se han demostrado las fuentes de mi cultura. Iríamos hasta lo ilimitado y además no sería necesario" ${ }^{131}$.

${ }^{29}$ Fernando Lázaro Carreter, "Imitación compuesta y diseño retórico en la oda a Juan de Grial”, Anuario de Estudios Filológicos II (1979) 89-119: el poeta, "ante una emoción que sacude su alma, busca en sus recuerdos de lector aquellos pasos que, en un antiguo - moderno- bueno y a ser posible óptimo, permitan expresarla".

${ }^{30}$ Victor Hugo, "Prólogo a Cromwell", en Manifiesto romántico, Ediciones Península (Barcelona 1989) 63.

31 “man könnte ebensogut einen wohlgenährten Mann nach den Ochsen, Schafen und Schweinen fragen, die er gegessen und die ihm Kräfte gegeben. [...] Ich verdanke den Griechen und Franzosen viel, ich bin Shakespeare, Sterne und Goldsmith Unendliches schuldig geworden. Allein damit sind die Quellen meiner Kultur nicht nachgewiesen, es würde ins Grenzenlose gehen und wäre auch nicht nötig. Die Hauptsache ist, daß man eine Seele habe, die das Wahre liebt, und die es aufnimmt wo sie es findet", Johann Peter Eckermann, Gespräche mit Goethe in den letzten Jahren seines Lebens. Ed. de Otto Schönberger, Reclam (Stuttgart 1994) 311. Corresponde a la fecha 16-12-1828. De la relación entre la parábola de las abejas y esta comparación de Goethe trata brevemente Moog-Grünewald en su trabajo "Investigación de las influencias y de la recepción", en Manfred Schmeling (ed.), Teoría y praxis de la literatura comparada. Alfa (Barcelona 1984) 88. Coleridge compara también los procesos que se operan en la imaginación secundaria con la asimilación que se produce cuando un organismo convierte los alimentos en su propia substancia. Samuel Taylor Coleridge, Biographia literaria, traducción y ed. española de E. Hegewicz, Editorial Labor (Barcelona 1975) 19-20 y 48-50. Carmen Martín Gaite responde a la pregunta “ ¿De qué autores se siente deudora?" con la misma imagen goetheana: "Recoger y hacer fructificar todo lo leído que un 
El que Goethe, contrario a la imitatio como técnica, use una imagen que había servido a los clásicos para defenderla, es ejemplo de hasta qué punto autores de todas las épocas y formaciones han aceptado que la literatura se alimenta de vida y de literatura conjuntamente, formando una cadena histórica de débitos, hurtos y guiños, lecturas y memorias de lecturas. La originalidad, ni siquiera la de un sturmunddränger, puede significar prescindir de las fuentes librescas. Lo afirma Goethe cuando tratando de nuevo con Eckermann, reconoce que si pudiera dar cuenta de todos los autores a los que algo debe, poco de su propia obra quedaría sin adjudicar ${ }^{32}$. Haciendo nada menos que la Historia del Romanticismo lo declaraba Teófilo Gautier en términos que pueden resultar muy paradójicos expresados por un romántico:

"En el arte, como en la realidad, siempre se es hijo de alguien, incluso cuando el padre es renegado por el hijo. [...] Todo hombre joven hizo su volumen de versos impreso a imitación del maestro preferido, y algunas veces mezclando varias imitaciones." 33

Que el Romanticismo no llegó a abolir definitivamente las técnicas de la imitación literaria, sino que éstas, renovadas y trasplantadas a un nuevo concepto de la actividad creadora, conocerán practicantes hasta en nuestros escritores más actuales, lo demuestran desde Eliot a Cernuda o Gil de Biedma ${ }^{34}$; éste no tuvo reparo en defender que

"la imitación es necesaria, es la única forma de llegar a escribir poesía. Uno escribe en función de lo que ha leído" ${ }^{35}$

Más que en Eliot o Gil de Biedma, que siempre mostraron su voluntad de presentarse como poetas que asumen la tradición y la usan, podría sorprender encontrar declaraciones semejantes incluso en autores tan poco canónicos como Arturo Pérez Reverte, que en una entrevista, y en tono que elude voluntariamente lo académico y erudito, reconocía

día nos emocionó se podría comparar a una digestión, cuyos elementos son inconsistentes a la hora de elaborar la propia obra", ABC Cultural, 27 de mayo de 2000, n 435, 12.

32 "Man spricht immer von Originalität, allein was will das sagen! [...] Wenn ich sagen könnte, was ich alles großen Vorgängern und Mitlebenden schuldig geworden bin, so bliebe nicht viel übrig” (12 de mayo de 1825), Eckermann, Gespräche, ed. cit., 167. Sobre las complejas relaciones de Goethe con la tradición, véase Hans Reiss, "Goethe und die Tradition", en Goethe und die Tradition, hrsg. von Hans Reiss, Athenäum-Verl. (Frankfurt/Main 1972) $15-25$.

${ }^{33}$ Teófilo Gautier, Historia del Romanticismo y Los progresos de la poesía francesa desde 1830, Iberia (Barcelona 1960) 185.

${ }^{34}$ Del primero véase su famoso "Tradition and the Individual Talent" (en Selected Prose of T.S. Eliot, ed. de F. Kermode, A Harvest Book (San Diego/New York/London 1975) 37-44). De Gil de Biedma es muy interesante sobre todo el trabajo "La imitación como mediación", en Edad Media y literatura comtemporánea, Trieste (Madrid 1985) 61-87. Vale al caso también la afirmación de Goytisolo en El bosque de las letras, Alfaguara (Madrid 1993) 27: el gran escritor "es una criatura voraz y vandálica que entra a saco en lo que halla a su alcance, se apodera de cuanto le interesa, manipula, digiere e integra cualquier clase de materiales en la armadura o ensamblaje de su propia creación. Todo, absolutamente todo, influye en él: un libro meditado o leído por casualidad, un recorte de periódico, un anuncio callejero, una frase captada en un café, una anécdota familiar, la contemplación de un rostro, grabado o fotografía."

${ }^{35}$ Cit. por Pere Rovira, La poesía de Jaime Gil de Biedma, Llibres del Mall (Barcelona 1986) 175. 
aprovechar la tradición novelística usando "unas herramientas de trabajo que otros inventaron antes que él". Por eso, en un ejercicio de memoria textual, vuelve a aquellos fragmentos que sabe le ayudarán en el pasaje concreto que escribe: para la preparación de personajes revisa a Galdós; para su tratamiento, a Conrad; el punto de vista es de Ford Madox Ford; para las reflexiones sobre el tiempo se fija en Thomas Mann:

"Lo que pasa es que hay que saber dónde buscar y hay que saber utilizar esos conocimientos. Y eso no tiene nada que ver con copiar. Cuando leo a Conrad para recordar una descripción del ruido del mar, me quedo con ese ruido, me voy a mi mesa y pienso en él. Luego puedo escribir mi propio ruido, mi propia percepción. Eso es muy divertido. Los libros de mi biblioteca están vivos, los consulto constantemente" ${ }^{36}$

De nuevo, como en las experiencias de José Hierro y Bécquer, se establece una distancia nemotécnica entre el objeto y la escritura, teniendo en cuenta además que en este caso la materia no es una percepción sensible o una reflexión propia, sino que es ya un objeto literario, materia literaria, de la que el autor se apropia y elabora: "me quedo con ese ruido, me voy a mi mesa y pienso en él. Luego puedo escribir mi propio ruido". Esto es: en el ejercicio de esta memoria textual la distancia entre el objeto, entre la materia, y su conversión poética en la palabra es aún mayor que en el caso de la memoria histórica, porque se da un proceso intermedio en el que dicho objeto se identifica primero con un texto anterior que lo literaturiza, y sólo una vez encarnado en literatura, se transforma en palabra nueva y personal. La forma en la que la tradición se incorpora a la obra de los escritores desde el Romanticismo ya no será, sin embargo, la de la imitación como tal técnica, sino más bien, a la manera que lo compara Fernando Sánchez Dragó, la de la resonancia en el interior de una caracola ${ }^{37}$; el autor gusta sentir su creación como otra onda integrada en la corriente de mareas de la literatura, un nuevo tono que armoniza con el recuerdo de las viejas frases musicales; y la memoria textual le proporciona los guiños secretos por los que establecer con su receptor una íntima camaradería de lectores cómplices, conmovidos por una misma emoción de viejas lecturas.

El tercer tipo de memoria, que llamaremos memoria asociativa, está íntimamente relacionada con la explicación mecánica de la imaginación. Ya para Platón la fantasía se forja con imágenes elaboradas a partir de improntas depositadas en la memoria; no copia, sino reconstruye por evocación las speciei que entran por los sentidos y se imprimen en el almacén de la memoria ${ }^{38}$. Después de él, desde Aristóteles y hasta el Romanticismo, se entiende que la imaginación funciona como una capacidad combinatoria asociada a la memoria, capaz de segmentar en orden espacial y temporal diferente del de la experiencia

${ }^{36}$ El País semanal, $\mathrm{n}^{\circ}$ 1052, 24 de noviembre de 1996.

37 "La literatura es un río en marcha cuyo punto de origen está en Homero, en Gilgamesh, en Lao Tsé, en el Genji Monogatari... Me siento hijo de todos los escritores, castellanos o no, que me han precedido. Me gustaría que mis libros fuesen una especie de caracola marina llena de resonancias". ABC Cultural, 3 de junio de 2000, nº 436, 12.

${ }^{38}$ Véase el magnífico trabajo de Guillermo Serés, "El concepto de Fantasía, desde la estética clásica a la dieciochesca", Anales de Literatura española, 10 (1994), 207-236, 208. 
original los contenidos en aquella depositados ${ }^{39}$. Según esta concepción, la poesía no es la reproducción de las sensaciones empíricas, ni de los objetos materiales, sino de la Idea que la memoria ha almacenado, recreado y transformado en la mente del sujeto. Herrera explicó en términos aristotélicos este proceso de formación de la Idea por la memoria:

"Porque siendo representada a nuestros ojos alguna imagen bella y agradable, pasa la efigie de ella por medio de los sentidos exteriores en el sentido común; del sentido común va a la parte imaginativa, y de ella entra en la memoria, pensando y imaginando se para y afirma [en] la memoria" ${ }^{40}$.

Y de su calidad de phantasma de la memoria, aquella imagen bella volverá a tomar cuerpo en la realidad a través de la forma poética. Por este proceso, la literatura viene a ser encarnación de las ausencias ("se canta lo que se pierde", en famosa expresión machadiana). Frente a la presencia de lo sensible, la memoria se alimenta de la ausencia; su única realidad es la realidad interior de los reflejos deformes del mundo real, simulacros de vida que sólo cobrarán identidad en la construcción de la substancia poética. Y precisamente la ausencia, que es la vida del deseo, es la marca de esa poética del recuerdo que cultivaron con tanto ahínco los petrarquistas, herederos de aquel Canzionere que cantase primero a madonna Laura nunca poseída y después a madonna Laura arrebatada por la muerte. El petrarquismo se lamentaba por una amada perdida, ingrata, ausente $o$ muerta, cuya imagen no se posee sino en ráfagas de dolidos recuerdos; la ausencia del objeto amado es el motivo del dolor poético, una ausencia que en parte puede volver a investirse de presencia trascendente -como de nuevo explica Herrera- gracias a esa imaginación-memoria,

"se representan de tal suerte en el ánimo las imágenes de las cosas ausentes, que nos parece que las vemos con los ojos, y las tenemos presentes, y podemos fingir y formar en el ánimo verdaderas y falsas imágenes a nuestra voluntad y arbitrio" ${ }^{41}$.

El poeta es el que custodia codicioso aquellas imágenes, el que busca traer de nuevo a la realidad $\multimap$ a la irrealidad literaria- lo que sólo sobrevivía como breve jirón de niebla en su recuerdo, el que resucita a la vida lo que se había perdido; es, como para Bécquer, aquél a

${ }^{39}$ El concepto aristotélico de fantasía o imaginación ha provocado inagotables discusiones, dadas las supuestas contradicciones, falta de consistencia y ambigüedades del capítulo 3 de De Anima. David Gallop, "Introduction" to Aristotle, On Sleep and Dreams, Aris \& Phillips Ltd. (Warminster 1996) 1-59, 22. Sin embargo, la imaginación es uno de los conceptos clave de la psicología aristotélica, pues explica nada menos que nuestro conocimiento del mundo sensible ya que "la facultad cognoscitiva piensa sus formas en imágenes" (De Anima 431b2); la imaginación es la capacidad para interpretar los fenómenos: el concepto (noema) de 'blanco' no existiría en nuestra mente sin el phantasma de 'blanco'. Gerard Watson, "Phantasia in Aristotle, De Anima 3,3", Classical Quarterly 32 (1982), 100-113. Es evidente la presencia de la teoría aristotélica en el conocido pasaje de Introducción a la Crítica de la razón pura de Kant: "no existe duda alguna sobre el hecho de que todo nuestro conocimiento proceda de la experiencia" puesto que "nuestra capacidad de conocer no se despierta sino a través de aquello que pasa por los sentidos, que provoca representaciones [imágenes] y que pone en movimiento nuestra actividad intelectual."

${ }^{40}$ Fernando de Herrera, Anotaciones a Garcilaso, ed. de A. Gallego Morell, Garcilaso y sus comentaristas, Gredos (Madrid 1972) H-62, 336-7.

${ }^{41}$ Herrera, Anotaciones, ed. cit., H-24, 322. 
quien le está dado "guardar, como un tesoro, la memoria viva de lo que ha sentido"42 y recuperarla en la emoción eterna del verso. Especialmente para la estética neoclásica, última heredera del neoaristotelismo, y a consecuencia de aquella íntima asociación entre memoria e imaginación, el poeta es, como afirmara Gottsched en su Kritische Dichtkunst de 1730 y antes que él Hobbes, el hombre que recuerda, y cuya imaginación, según frase de Hobbes, es sólo 'a sort of decaying memory' ${ }^{43}$.

Las que proporciona esta imaginación mecánica anterior al Romanticismo resultan imágenes que son réplica de las que reciben los sentidos aunque, como se decía, en la reflexión que las trae de nuevo a la mente rescatándolas de la memoria, puedan sufrir una alteración distributiva y ser combinadas en orden distinto al natural y en asociación con otras imágenes. La imaginación sirve pues para recuperar imágenes o combinarlas, no las $\mathrm{crea}^{44}$; sublima la materia, pero no la inventa. Se comporta como una especie de memoria. Con el cuarto tipo de que a continuación vamos a tratar, la memoria creadora, hija del Romanticismo, la imaginación es facultad de transformación que sirve, en expresión de Schlegel, para «poetizar el mundo»; es una fuerza productora, independiente de las percepciones sensoriales y del control del entendimiento. Está asociada al concepto de creación tal como se introdujo en la cultura europea "no a través del arte, sino a través de la religión cristiana, uno de cuyos dogmas es la creación del mundo por Dios: «In principio creauit Deus coelum et terram» (Gen. 1.1)" ${ }^{\text {"45 }}$. Pero también tiene relación con el concepto de genio -no en vano es durante el Sturm und Drang cuando fecunda la memoria creadora-, voz cuya etimología nos pone en contacto con el griego génos, 'engendrar', y también con el daimon platónico, "mensajero entre el cielo y la tierra, entre la divinidad y la humanidad"46.

La cosmovisión anterior al Romanticismo concebía el mundo atomísticamente, compuesto de detalles y de individualidades diferenciadas como entidades autónomas. Una cosmovisión que se corresponde con la imaginación mecánica, y en la práctica poética, con la memoria textual y la memoria asociativa, que proceden a partir de motivos que se superponen, de imágenes, versos o escenas que se distribuyen sobre el plano de la creación. Con el Romanticismo, y ya en los movimientos que lo preceden, la nueva Weltanschauung sentirá honda repulsión por aquel sistema de explicación mecanicista de la naturaleza, antipatía de la que puede ser ejemplo la que manifestara Goethe por la obra de Holbach ${ }^{47}$.

\footnotetext{
${ }^{42}$ Ver cita supra.

${ }^{43}$ Cit. por Lilian R. Furst, Romanticism in Perspective, Methuen (Londres 1969) 127. Maurizio Ferraris, La imaginación, Visor (Madrid 1999) 14. historia del concepto". En Historia de seis ideas, Tecnos (Madrid 1996) 279ss.

${ }^{46}$ Antoni Marí, Euforión. Espíritu y naturaleza del genio, Tecnos (Madrid 1989) 22-24.

${ }^{47}$ Meyer H. Abrams, El espejo y la lámpara, Barral (Barcelona 1975) 327ss.
}

${ }^{44}$ Puede distinguirse, como hace Ferraris siguiendo el valor de los términos latinos, la función de la fantasía de la de la imaginación: "si por un lado imaginatio se diluye en la percepción (visio) y en la memoria (...), por otro phantasia parece absorber, en forma degradada, las mismas funciones de composición y descomposición que pertenecen al concepto. La imaginatio proporciona el hombre y el caballo, la phantasia compone el centauro", vid.

${ }^{45}$ Y así el primero en usar la expresión "poeta creador» añadiría: «instar Dei». W. Tatarkiewicz, "La creatividad: 
Frente a la estructura compositiva, la modernidad quiso ver cualquier entidad individual como parte de un gran Absoluto al que pertenece y en el que se integra. La imaginación por tanto habrá de actuar como creación total, no puede ser ya un proceso de combinación de partes, sino la acción de descubrir el magnífico Todo superior del que somos miembros ${ }^{48}$. Buscando una visión del mundo que lo explicara como un conjunto orgánico, se recurrió a la tradición neoplatónica: el Timeo había propuesto la figura del Demiurgo, cuyo aliento infundió el anima mundi, concepto que -tras retornar con variaciones en diversos filósofos de aquella tradición neoplatónica-, fue elaborado como "metafísica coherente y omnicomprensiva" en la teoría romántica alemana de la Weltseele. Por otra parte, el Fedón platónico presentaba a la memoria humana una vía de acceso a la visión totalizadora: allí se explicaban los recuerdos como consecuencia de la preexistencia del alma inmortal antes de encarnarse, cuyo conocimiento del mundo de las ideas guardó en la memoria ${ }^{49}$. Trasladando a la nueva mitología el papel del demiurgo, ahora bajo la apariencia del sueño, el Romanticismo sintió que la poesía absoluta florece por sí misma a partir de la fuerza original de la humanidad, una fuerza invisible relacionada con el mundo interior, con la oscuridad de nuestro abismo y universo onírico. El papel de la memoria habrá de adoptar nuevos valores en el seno de esta poética. En primer lugar porque si hasta ahora la omnipresente tradición literaria obligaba a mirar el pasado, a remitirse al almacén de la memoria textual, el Romanticismo supone una invitación a la innovación, a anticipar el futuro. Pero sobre todo porque la nueva edad "drew its heavy line between the artificial and the natural" 50 y, una vez que la correspondencia entre naturaleza y arte se observe como fuente de irresolubles conflictos, la poética moderna habrá de reconocer que el combate con la forma, aquel que se deriva de la relación entre el artista y su medio de expresión, no es ya lo problemático, sino el que se establece entre el artista y su experiencia: en palabras de Claudio Guillén, "el campo de batalla de no pocas poéticas modernas sería la actitud del escritor ante el «principio de realidad»" ${ }^{\prime 51}$. La memoria literaria ya no puede ser por tanto el

${ }^{48}$ Rolf Breuer, “Coleridge's Concept of Imagination -with an Interpretation of Kubla Khan”, en Harry R. Garvin (ed), Romanticism, Modernism, Postmodernism. Associated University Presses (Lewisburg 1980) 52-66, 54.

49 "tras haberlo adquirido [el conocimiento] antes de nacer, lo perdimos en el momento de nacer, y después, gracias a usar en ello de nuestros sentidos, recuperamos los conocimientos que tuvimos antaño, ¿no será lo que llamamos aprender el recuperar un conocimiento que era nuestro? Y si a ese proceso lo denominamos recordar, ¿no le daríamos el nombre exacto?”. Platón, Fedón o del alma, en Obras completas, ed. cit., 623. Muy útil también podía resultar a la nueva búsqueda romántica la interpretación del Ión, cuando afirma que la inspiración de los poetas, como la de los profetas y adivinos, procede de la posesión divina en arrebato inconsciente, lo que les convierte en intérpretes y mensajeros de la divinidad: "el poeta [...] no está en disposición de crear antes de ser inspirado por un dios, [...] ni antes de haber dejado de ser dueño de su razón", Ión o sobre la «Iliada», 534a-525 ed. cit., 146-7.

${ }^{50}$ Harry Levin, "Notes on Convention", Perspectives of Criticism, Cambridge University Press (Cambridge, Mass., 1950) 73.

51 C. Guillén, Teorías de la Historia literaria, Espasa-Calpe (Madrid 1989)110: "La rebelión contra las convenciones, o contra la literatura misma, era una reacción, en el fondo, contra las poéticas neoclásicas. El surgir de una poética nueva, basada en el poder de la imaginación, alteraría por completo los términos del problema. Mientras se seguía admitiendo la identidad neoclásica del arte con la naturaleza, toda convención formal podía parecer un estorbo. Pero si el valor del arte consistía en cierta liberación de los «límites de lo real», o en un enriquecimiento y una nueva exploración o indagación de lo real [...], entonces toda convención artística podía convertirse en un aliado. Las convenciones artísticas, en última instancia, no eran el blanco adecuado." 
recuerdo de la experiencia, de aconteceres que se conectan, sino el recuerdo del mundo como imaginario. Superior a la vivencia física, inventa otras vidas y otros pasados que nunca tuvieron lugar pero que se hacen verdad por la literatura: en carta a Alejandro Dumas, -y como respuesta al artículo prematuramente necrológico que éste le dedicara en Le mousquetaire en 1853-, tratando de la pérdida de la razón por la imaginación, Nerval trata con romántico desvarío en unas líneas fascinantes la confusión entre vida y literatura:

"Lo que para usted, maestro -que tan bien ha sabido divertirse con nuestras crónicas y memorias que la prosperidad no sabrá separar lo cierto de lo falso, [...]-, no hubiera sido más que un juego, a mí se me había vuelto una obsesión, un vértigo. Inventar, en el fondo, es recordar, dijo un moralista; al no poder hallar las pruebas de la existencia material de mi héroe, creí de pronto en la transmigración de las almas"

Si los tres tipos de memoria tratados hasta el momento eran perfectamente compatibles entre sí, la nueva memoria romántica, aunque no invalida por completo las anteriores, sí las domina y enseñorea y reduce considerablemente su competencia en la creación: no ha de ser la memoria de los grandes hechos del pasado, ni memoria de la literatura, ni tampoco memoria de lo percibido, sino solamente memoria de lo imaginado, de lo inventado, de lo que la mente es capaz de entrever, no con los sentidos, sino con sus facultades visionarias. En sus Conjectures on Original Composition de 1759, Edward Young anima al poeta a zambullirse hondo en su profundo abismo interior, a "contraer plena intimidad con el extraño que está en ti", con ese otro-yo (no hace falta recordar cómo el tema del doble cobra su más inquietante presencia en la literatura romántica) genial y subliminal. Ese encuentro trae al pensamiento las ideas latentes, vivas pero desconocidas, habitantes interiores que demuestran, como en Platón y ahora en Leibniz, que ninguna idea es del todo nueva, sino que en todo caso dormita silenciosa en lo más profundo de nuestra conciencia ${ }^{53}$. Johann Georg Sulzer en artículo Begeisterung (Inspiración) de la Allgemeine Theorie der schönen Künste -que recibiera tan duros ataques de Goethe ${ }^{54}$-, trata de aplicar tal misterio psicológico al terreno de la invención del artista:

Es cosa conocida por experiencia, pero difícil de explicar, que los pensamientos y las ideas que se siguen de la persistente contemplación de un objeto -...- se recogen juntos en el alma y allí germinan sin tenerse noticia de ellos, como semillas en un suelo fructuoso, y finalmente, en el momento apropiado, salen a luz repentinamente... En ese instante vemos el objeto relevante -que hasta entonces había revoloteado ante

\footnotetext{
${ }^{52}$ Con su característica ironía romántica, le recuerda a Dumas cómo ya Nodier se identificaba hasta tal punto con sus criaturas literarias que se confundía con ellas: "con qué convicción contaba nuestro viejo amigo Nodier cómo había tenido la desgracia de ser guillotinado en la época de la Revolución; uno se lo creía de tal manera que se preguntaba cómo había conseguido que volvieran a pegarle la cabeza..." Gérard de Nerval, prólogo a Las hijas del fuego, ed. de Fátima Gutiérrez, Cátedra (Madrid 1990) 73.

${ }^{53}$ Sobre el papel de Leibniz en la superación del mecanicismo cartesiano a través de explicaciones ya no corporales sino psicológicas, véase Ernst Bloch, Philosophische Aufsätze zur objektiven Phantasie, Suhrkamp (Frankfurt am Main 1985) 90ss.

${ }^{54}$ Se trata de una reseña muy crítica escrita en diciembre de 1772 para el Frankfurter Gelehrten Anzeigen. Ver Heinz Hamm, Der Theoretiker Goethe. Grundpositionen seiner Weltanschauung, Philosophie und Kunsttheorie, Akademie Verlag (Berlin 1980) 169-172.
} 
nosotros oscura y confusamente como un fantasma informe- irguiéndose ante nosotros en su forma clara y completa. Este es el genuino instante de la inspiración $^{55}$.

Se trata casi una memoria demiúrgica que, como la platónica, nos trae recuerdos del mundo de las ideas en el que habitábamos antes de nuestro nacimiento; eso la hace superior a toda experiencia personal y a cualquier forma de pensamiento lógico: por ella podemos volver a vislumbrar y presentir aquella Unidad del Universo en comunión que fue nuestro seno primero. La poesía, cuya misión es cantar esa unidad sagrada, se presenta otra vez como un ejercicio de memoria para recordar lo que fuimos antes de nacer al mundo de la razón. Perdidas ya las apoyaturas de la representación, la memoria no puede funcionar mecánicamente: ahora es libre y se relaciona con el sueño. Por eso Bécquer en la Introducción sinfónica a sus Rimas, apartándose ya del proceso por él mismo descrito algunos años antes, reconoce,

"Me cuesta trabajo saber qué casos he soñado y cuáles me han sucedido; mis afectos se reparten entre fantasmas de la imaginación y personajes reales; mi memoria clasifica, revueltos, nombres y fechas de mujeres y días que han muerto o han pasado con los de días y mujeres que no han existido [sino] en mi mente" ${ }^{\text {,56. }}$

En este proceso de redescubrimiento visionario, la memoria juega una función casi mágica por la que en determinados momentos el poeta puede sentir, recordar, la conexión entre todos sus pensamientos, y entre su ser y todas las cosas, como lo explica Schlegel en Lucinde:

"jeder Gedanke und was sonst gebildet in uns ist, scheint in sich selbst vollendet, einzeln und unteilbar wie eine Person; [...] Und dann gibt es doch wieder Augenblicke plötzlicher, allgemeiner Klarheit, wo mehrerę solche Geister der inneren Welt durch wunderbare Vermählung völlig in eins verschmelzen und manches schon vergessene Stück unsres Ich in neuem Lichte strahlt und auch die Nacht der Zukunft mit seinem hellen Scheine öffnet" ${ }^{57}$.

\footnotetext{
${ }^{55}$ Allgemeine Theorie der schönen Künste, I, 349. Cit. por Meyer H. Abrams, El espejo y la lámpara, op. cit. 360. Cita además Abrams un pasaje paralelo, también de la Allgemeine Theorie der schönen Künste (II, 88, artículo 'Erfindung', Invención): "Es cosa notable, que pertenece entre otros a los misterios de la psicología, que a veces ciertos pensamientos no se desarrollan o se dejan captar claramente cuando les dedicamos toda nuestra atención, a pesar de lo cual mucho después se presentan por sí solos con la mayor claridad y por propia decisión, cuando no andamos en busca de ellos, de modo que parece como si en el ínterin hubieran crecido sin saberlo nosotros, como una planta, y ahora repentinamente se está ante nosotros en pleno desarrollo y florecimiento. [...] Todo artista debe confiar en tales felices expresiones de su genio, y si no siempre encuentra lo que diligentemente busca, debe esperar con paciencia la maduración de sus pensamientos".
}

56 Y cabe también recordar el texto de "Entre sueños", que según Leonardo Romero Tobar es donde mejor demuestra Bécquer cómo acabó adoptando el nuevo concepto de imaginación romántica: en ese artículo explica que "La imaginación" se apodera de las sensaciones exteriores, y desfigurándolas y dándoles una forma extraña, las asimila a sus "extravagantes desvaríos". Romero Tobar, "Bécquer, fantasía e imaginación", Actas del Congreso «Los Bécquer y el Moncayo», Institución Fernando el Católico (Ejea de los Caballeros 1992) 171-189, 188.

57 Lucinde, 15. Véase también de los Fragmente el 37: “Manche witzige Einfälle sind wie das überraschende Wiedersehen zwei befreundeter Gedanken nach einer langen Tennung”. 
Durante esos 'instantes' repentinos de iluminación los espíritus del mundo interior, en ese ayuntamiento prodigioso de las ideas, nos muestran como en un rayo de luz -Bécquer los sentía o los describía precisamente como "hilos de luz"58 - el último pasado de nuestro Yo y la noche del futuro.

De esta teoría de la imaginación y la memoria construida por Schlegel, el concepto llegó a la poética del Romanticismo inglés interesando en primer lugar a Coleridge, estudiante en Alemania y que mantuvo relación directa con los de Jena. Del planteamiento de Schelling y las teorías schlegelianas parte su famosa diferenciación entre fantasía e imaginación, expuesta en la Biographia Literaria de $1817^{59}$. Coleridge, además, se interesa por otro punto de las enseñanzas alemanas: la posibilidad de la poesía para reunir el pasado con el presente, o por expresarlo en palabras de Schlegel en Lucinde: "daß, was wir jetzt nur Hoffnung nennen, eigentlich Erinnerung war"60. Esta facultad libera de las dimensiones espacio-temporales, que dejan de ser fronteras que puedan imponérsele al hombre, capaz de superar todas aquellas contingencias desde su esencia trascendente y en su nueva poesía trascendental. Por ello, para Coleridge, como para Schlegel o Novalis, la verdadera poesía supera los límites del espacio y el tiempo: así en las Sagradas Escrituras, modelo de esta lírica eterna, el pasado y el futuro están contenidos en el presente, puesto que la historia sagrada es profética e histórica a la vez; en la Biblia, por la magia de la palabra poética, todo tiene doble significado: el temporal y el eterno, el particular y el universal, la memoria del pasado y el vaticinio del futuro ${ }^{61}$.

Si la imaginación mecánica funcionaba como una suerte de memoria, ahora la memoria creadora se vuelve imaginación y, en relación con lo sobrenatural y misterioso, nos pone en contacto con ese pasado anterior a nuestro nacimiento y a nuestra conciencia. Se podría

\footnotetext{
58 "Un mundo de ideas se agolpó a mi imaginación en aquel instante. Ideas ligerísimas sin forma determinada, que unían entre sí, como un invisible hilo de luz, la profunda soledad de aquellos lugares, el alto silencio de la naciente noche y la vaga melancolía de mi espíritu", La cruz del diablo. Leyendas, ed. de Ana Rodríguez-Fischer, PPU (Barcelona 1992) 310. Sobre la metáfora del "hilo de luz", v. Jorge Guillén, "Bécquer o lo inefable soñado". En Lenguaje y poesía. Algunos casos españoles, Alianza (Madrid 1969) 121.
}

${ }^{59}$ Samuel Taylor Coleridge, Biographia literaria, ed. cit. 19-20 y 48-50. Véase Monroe C. Beardsley y John Hospers: Estética. Historia y fundamentos, Cátedra, (Madrid 1990) 66. A. W. Schlegel, en las Vorlesungen über schöne Literatur und Kunst distingue, siguiendo a Schelling, Einbildungskraft de Fantasie: Einbildungskraft es facultad inferior, frente a Bildungskraft o Phantasie, una 'imaginación creadora', absolutamente libre y lícita, sin restricciones, que es la verdadera fuerza poética y está vinculada a la razón.

${ }^{60}$ Lucinde, 15.

${ }^{61}$ Según Coleridge es ésta la más preciosa de todas las literaturas, la que logra reunir la unidad temporal en un presente eterno; véase Ina Lipkowitz, "Inspiration and the Poetic Imagination: Samuel Taylor Coleridge", Studies in Romanticism XXX (1991), 605-631, 619. Todavía dentro de la literatura inglesa, la memoria será primero para Shelley -discípulo de las teorías de Coleridge-, y después para su admirador y seguidor Browning, recurso fundamental de la creación. Pero la memoria entendida de nuevo en el sentido platónico: no se trata de recordar lo sucedido, sino lo que se sabía sin conocerlo, lo que nunca se ha visto antes. El acto de percepción no se refiere sólo al presente, sino gracias a la memoria, también al ajeno pasado, memoria que es capaz de convertir en presente lo que fue y, sobre todo, hacer de nuevo nuestro aquello que se había perdido: "Memory becomes a species of imagination, recollecting shadowy "faint blooms» that never grew on land or sea". Herbert F. Jr. Tucker, "Memorabilia: Mnemonic Imagination in Shelley and Browning", Studies in Romanticism XIX (1980), 285-326, 288-9, 292 у 295. 
entender incluso que el mito de la memoria para Shelley anticipa la mítica topografía del subconsciente freudiano. Porque especialmente insiste Shelley en la capacidad de la memoria y de sus frutos literarios para trascender las fronteras temporales, pues el lenguaje de los poetas "perpetúa la percepción [de las cosas]", es decir, el lenguaje poético convierte las cosas en realidades eternas ${ }^{62}$ :

\begin{abstract}
"Un poeta [...] no sólo contempla intensamente el presente tal como es, [...], sino que contempla en el presente lo futuro [...] Un poeta tiene parte en lo eterno, en lo infinito, en lo único; en cuanto se refiere a sus concepciones, tiempo, lugar y número no existen. Un poema es la imagen total de la vida expresada en su eterna verdad [...] La Poesía levanta el velo de la oculta hermosura del mundo, y transforma los objetos familiares: reproduce cuanto representa, y las personificaciones envueltas en su luz inmortal, perduran de allí en adelante en el espíritu de los que una vez las contemplaran, como memoriales de aquel gozo amable y exaltado que se derrama sobre todos los pensamientos y acciones con que coexiste"
\end{abstract}

A pesar de que resulta inevitable poner en relación estas palabras con otras muy semejantes de la teoría poética becqueriana, no debe pensarse que fue fácil y rápida la difusión de estas ideas entre nuestros poetas españoles. Tanto el Romanticismo francés, como su discípulo en tantas cosas, el español, siguiendo más bien la línea de Rousseau o Bernardin de Saint-Pierre y Chateaubriand, entienden que la novedad de la revolución romántica consiste en una literatura que sea confesión de la emoción melancólica, recuerdo emocional de lo vivido y experimentado ${ }^{64}$. Apenas se plantean -salvo en ciertos ecos esproncedianos, esporádicos lugares de autores secundarios y en algunos breves apuntes en artículos de prensa-, al menos hasta ya cumplido mediados del siglo XIX, las mucho más fecundas posibilidades de esa otra nueva imaginación creadora de la que trataran las escuelas alemana e inglesa y que sólo triunfará después de Bécquer, cuando el posrromanticismo y el Simbolismo difundan por tierras francesas y españolas los revolucionarios avances de Jena. De ahí que probablemente el descendiente español más notable de esta herencia poética sea el Valle-Inclán de La lámpara maravillosa, quizá la más intensa poética del Modernismo romántico, además de uno de los mejores tratados místicos de la literatura española.

El volumen, publicado en 1916, es una poética escrita en clave gnóstica, en la que Valle pone en acción todos sus conocimientos teosóficos y ocultistas siguiendo así una de las orientaciones fundamentales de la estética contemporánea, la vertiente hermética, que es a su vez continuación de la vía abierta en esta dirección por el primer Romanticismo alemán. Indudablemente, La Lámpara Maravillosa recoge, en su recorrido místico por el acto poético, el legado de la teología lírica de Novalis y de Schleiermacher, con toda la estética universalista y trascendental de los Frühromantiker. Para sentir la cercanía del texto de

\footnotetext{
${ }^{62}$ Percy B. Shelley, Defensa de la poesía. Ed. bilingüe de José Vicente Selma, Ediciones Península (Barcelona 1986) 26.

${ }^{63}$ Percy B. Shelley, Defensa de la poesía. Ed. cit. 27-8, 31 y 35.

${ }^{64}$ Vid. el artículo de Margery Sabin, "Imagination in Rousseau and Wordsworth", Comparative Literature XXII (1970), 4, 328-345, 332, donde se indica más bibliografía.
} 
Valle-Inclán con las posiciones del Romanticismo visionario no hace falta más que comparar su peregrinaje con el de Heinrich von Ofterdingen, u observarlo a la luz de ciertas posiciones de Shelley en aquella misma Defensa de la poesía mencionada antes y que, como La Lámpara Maravillosa, es también una poética mística ${ }^{65}$. Escribía Shelley:

"La Poesía es el recuerdo de los momentos mejores y más felices gozados por las almas mejores y más felices. Cuidamos de las evanescentes visitaciones del pensamiento y del sentimiento [...] y siempre llegando imprevistas y alejándose espontáneas, pero elevadoras y deleitables sobre toda expresión: [...] Es como si acaeciera la interpenetración de una [naturaleza] más divina dentro de la propia nuestra" ${ }^{66}$.

También para Valle-Inclán el recuerdo es el principio estético por antonomasia y la memoria el principio activo de la creación ${ }^{67}$ :

"En nuestras creaciones bellas y mortales, las imágenes del mundo nunca están como los ojos las aprenden, sino como adecuaciones al recuerdo. [...] El recuerdo da a las imágenes la intensidad y la definición de unidades al modo de una visión cíclica. El recuerdo es la alquimia que depura todas las imágenes, y hace de nuestra emoción el centro de un círculo, igual al ojo del pájaro en la visión de altura. [...] Las cosas no son como las vemos sino como las recordamos.[...] todas acendran su belleza en los cristales del recuerdo, cuando se obra la metamorfosis de los sentidos en la visión interior del alma [...] Todo el saber es un recuerdo",68.

Es en el recuerdo cuando se da ese momento prodigioso del que habló Schlegel en Lucinde, esa revelación mágica de las correspondencia que Bécquer llamaba el "hilo de luz" y por la que se ponen en relación todas los seres y las cosas, haciéndonos sentir la unidad mística del universo. En ese instante, también para Valle-Inclán, el alma supera las contingencias temporales y siente su eternidad al unir el pasado con el presente ${ }^{69}$. Con la

${ }^{65}$ Vid. mi reciente trabajo: "La lámpara maravillosa de Valle-Inclán y el Heinrich von Ofterdingen de Novalis o la poética como «camino de perfección», Revista de Literatura LXIV (2002) 127, 121-150.

${ }^{66}$ Shelley, Defensa de la poesía, ed. cit. 60.

${ }^{67}$ Javier Gómez Montero, "Valle-Inclán y la alquimia del recuerdo. Poética y representación de la memoria en $L a$ Lámpara Maravillosa y El Pasajero", Letras de la España Contemporánea. Homenaje a José Luis Varela. Ed. de Nicasio Salvador Miguel, Centro de Estudios Cervantinos (Alcalá de Henares 1995) 171-183.

${ }^{68}$ Recojo varias citas de La Lámpara Maravillosa, ed. de Javier Blasco Pascual, Espasa-Calpe (Madrid 1995) 137 y 145. Véase también la crítica que hizo Valle a Señora ama de J. Benavente (1908), según cuenta a su vez Gómez de la Serna (en Don Ramón M. del Valle-Inclán, Espasa-Calpe (Buenos Aires 1944) 107). Y en una crónica sobre J. Romero de Torres publicada en El Mundo del 3 de mayo de 1908: "Este gran pintor [...] sabe que para ser perpetuada por el arte no es la verdad aquello que un momento está ante la vista, sino lo que perdura en el recuerdo", en Valle-Inclán, Artículos completos y otras páginas olvidadas, ed. de Javier Serrano Alonso, Istmo, (Madrid 1987) 25. Cit. por Leda Schiavo, "La estética del recuerdo en Valle-Inclán", Ínsula 531 (marzo 1991), 1213.

69 "Al caminar bajo la sombra sagrada de los recuerdos (...) comprendía que nada de mi psiquis era abolido. Hasta entonces nunca había descubierto aquella intuición de eternidad que se me mostraba de pronto al evocar la infancia y darle actualidad en otro círculo de tiempo". Creo que no es improcedente recordar cómo desde la especulación filosófica Ernst Bloch entiende que el arte no es sólo medio de conocimiento del pasado, sino que en su teoría expresionista de la utopía lo presenta como la forma genial de transgresión y método de anticipar lo que 
memoria, en el recuerdo, se adquiere esa perspectiva aérea sobre la vida, sobre el propio pasado, que vuelve a ser presente y vaticinio de futuro; con la memoria lo recordado se vuelve imagen eterna, más allá del tiempo y el espacio, relacionada con ese primer momento del Génesis. En La lámpara maravillosa, el poeta-peregrino "primero viaja hacia adentro por la memoria de sus vidas anteriores. Después de haber alcanzado el conocimiento de su ser colectivo, está preparado para lograr la visión del Gran Todo"70. La vida, observada en esta perspectiva, se extiende más allá de sus límites y en vez de una línea horizontal, concluye en la perfección del círculo mágico del karma. Según Dolores Romero, "Esta forma de volver a lo primitivo para dar luz al presente es una necesidad de la fantasía moderna y en ella se adivina la conciencia de un artista que quiere separarse del tiempo histórico, diezmado ya por el nuevo progreso técnico e industrial"71; contra ese progreso que el modernista entiende negativo, contra el avance de una historia que nos reduce a piezas de la anónima maquinaria, la memoria creativa trae a la presencia del poeta una historia no contada, no sucedida en la experiencia visible, sino una historia trascendente a la que desde el Romanticismo el artista moderno siente pertenecer ${ }^{72}$, un pasado que quiere hacerse presente en la recuperación de la unidad original del paraíso: la de «las cinco rosas de la memoria»:

"Y ahora, alma mía, sólo tienes cinco caminos de tierra por donde volver al goce quieto del mundo, cinco estrellas se encienden sobre ellos, y abren sus círculos en la noche oscura: son las cinco rosas de la memoria"73.

aún no es, el futuro, el mundo nuevo, pues funciona como espejo de las cuestiones sobre la esencia del Yo y el mundo. Ernst Bloch, Philosophische Aufsätze zur objektiven Phantasie, Suhrkamp (Frankfurt am Main 1985) 87 ss.

70 "Voy por el mundo con los ojos vueltos atrás, estoy lleno de recuerdos como si hubiese vivido mil años. En una gran tiniebla, sobre un vasto mar de naufragio, se representa mi vida." Ver Dolores Romero López, "Aromas de leyenda a la luz de La lámpara maravillosa", en Valle-Inclán y su obra. Actas del Primer Congreso Internacional sobre Valle-Inclán, Universidad Autónoma de Barcelona (Bellaterra 1995) 407-417, 408, y Virginia Milner Garlitz, "Valle-Inclán y el ocultismo: la conexión gallega", en El Modernismo. Renovación de los lenguajes poéticos. Coord. por T. Albaladejo, Javier Blasco y R. de la Fuente, Universidad de Valladolid (Valladolid 1990) 61-80, 78 .

${ }^{71}$ Romero López, art. cit. 408.

${ }^{72}$ Gonzalo Sobejano explica que Valle, prefiere ver la historia "como leyenda. Su idealismo le hace mirar con simpatía, en el pasado español, aquello que, por carecer de vigencia actual, es sólo recuerdo, o esperanza, susceptibles de recreación personal"; incluso si Valle-Inclán ama la leyenda, lo hace "porque no reflejan realidades como el mundo las muestra, porque evocan y proyectan, -alusión, arquitectura- un mundo ausente, engrandecido". Gonzalo Sobejano, "Valle-Inclán frente al realismo español", en Anthony N. Zahareas, ValleInclán. An appraisal of this life and works, Las Américas (New York 1968) 159-171, 162-3, 164 y 165.

${ }^{73}$ La Lámpara Maravillosa, ed. cit. 145. 
